\section{Ethical sourcing of dental instruments and materials}

\author{
P. T. Kelly and M. Bhutta ${ }^{2}$
}

IN BRIEF

- Raises awareness that some dental materials and instruments may be manufactured under unethical working conditions, particularly in the developing world.

- Encourages the dental team to inquire as to the origin of materials and instruments, and the conditions under which they are produced.

- Proposes a higher profile for this issue in the dental-ethical agenda.

There is evidence that dental instruments and materials are being manufactured in the developing world under poor labour conditions. It is suggested that the level of awareness of the dental team with regard to this is raised and that a culture of greater inquiry into the sourcing of instruments and materials is developed.

The sourcing of instruments and materials for health care has been, for many years, largely unquestioned. However, recently the Medical Ethical and Fair Trade Group (fairmedtrade.org.uk), supported by the International Department of the British Medical Association, has raised awareness regarding poor labour conditions in the manufacture of a number of medical products. ${ }^{1}$ To date there has been little penetration of this issue into the field of dentistry. The volume and types of instruments and materials known to be made under poor working conditions suggest that at least some dental instruments and materials used in the UK are at risk of having been manufactured in unethical conditions. Dental instruments are certainly manufactured in countries ${ }^{2}$ where unethical working conditions in the manufacture of surgical instruments have been known to exist. ${ }^{3}$ This article has two main aims: to raise awareness within the dental profession of the risk that some instruments and materials are likely to have been manufactured under poor working conditions, and also to encourage questioning by purchasers at each level of the supply chain about the conditions under which instruments and materials are manufactured.

${ }^{*}$ General Dental Practitioner, Milford House, 8 Stottingway Street, Weymouth, Dorset; ${ }^{2}$ Research Fellow, University of Oxford, Oxford and Founding Member,

Medical Fair and Ethical Trade Group

${ }^{*}$ Correspondence to: Dr Paul Kelly

pklocum@hotmail.co.uk

\section{Refereed Pape}

Accepted 12 July 2010

DOI: $10.1038 /$ sj.bdj.2010.925

${ }^{\bullet}$ British Dental Journal 2010; 209: 377-379

\section{THE SUPPLY CHAIN}

Whereas there is evidence that labour abuses in the manufacture of healthcare products may be widespread, ${ }^{4}$ the area where this is most clearly documented is in the production of surgical instruments. ${ }^{5-6}$

The areas that manufacture the most surgical instruments are Tuttlingen (Germany) and Sialkot (Pakistan). ${ }^{6}$ Firms in these areas also manufacture dental instruments. ${ }^{2}$ Both Tuttlingen and Sialkot have over 300 manufacturers of surgical instruments ${ }^{7}$ and, although they are widely separated geographically, they have close trading and manufacturing links with each other.7 Tuttlingen has an estimated workforce of 6,000 and supplies two thirds of the world's surgical instruments, usually through direct trade to end users. ${ }^{7}$ Companies in Sialkot are representative of the manufacture of surgical instruments in the developing world, with most instruments manufactured and finished by hand. ${ }^{6}$ Production is therefore more labour intensive, employing 50,000 people to supply one fifth of the world's surgical instruments. ${ }^{6}$ Many instruments that are traded through, or finished, in Tuttlingen originate from Sialkot, ${ }^{7}$ although Tuttlingen is a significant location of surgical instrument manufacture in its own right. ${ }^{7}$ Pressure from developed countries for manufacturing to attain IS09000 quality standards, and the subsequent achievement of this by many firms in Sialkot, has allowed firms in Tuttlingen to source more instruments from Sialkot.?

Companies in Tuttlingen have a surgical instrument manufacturing profile which is more dependent on specialist technology to manufacture products such as endoscopes and implants, in addition to more traditional instruments. ${ }^{7}$ However, the strength of Sialkot has been described as being in 'lower quality, relatively cheap and high volume disposable instruments.? Downward pressure on purchase price from health care organisations and endusers has resulted in much manufacturing being diverted to where labour is cheaper, with manufacturers in developed countries taking on a greater role in trading and other activities such as maintenance and repair, or instrument tracking activities. ${ }^{7}$ The trend towards the increased use of disposable instruments may increase the proportion of instruments derived from Sialkot as firms there are known to make many disposable instruments., ${ }^{2,7}$

The leading global markets for surgical instruments are the USA, the European Union and Japan. ${ }^{7}$ Annual worldwide exports of hand held surgical instruments have been estimated at $\$ 1$ billion, although this figure is difficult to disaggregate from general medical instruments and appliances. ${ }^{7}$ The value of what are described as 'medical and orthopaedic etc equipment' imports into the UK in 2009 was $£ 4.1$ billion. ${ }^{8}$ In 2003 it was estimated that the annual total retail market for professional dental products, excluding over-the-counter sales of consumer dental products, was $£ 480$ million. ${ }^{9}$

In 2008, within the context of the EU framework for corporate social responsibility, ${ }^{10}$ the NHS Purchasing and Supply Agency (now decommissioned) published 
Ethical procurement for health guidance, ${ }^{11}$ which stated as an aim: "to build an awareness and understanding of labour standards in supply chains. ${ }^{11}$

\section{LABOUR CONDITIONS}

There are ethical concerns about many manufacturing industries throughout the world, with reports of unhealthy, unsafe and unfair working conditions including exposure to hazardous conditions, use of child labour and unfair contractual obligations. $^{12}$

Manufacturers of medical goods in the developing world may come under pressure from trans-national corporations with the result that prices and labour standards may be driven down. The initial manufacture of surgical instruments involves die making, forging, filing, grinding, machining, electroplating, and heat treatment., ${ }^{3,6}$ Most of these processes are subcontracted to small workshops, with only the final stages and quality checking conducted by the end producers. ${ }^{2,7}$ Subcontracting reduces costs and overheads but, because subcontractors are not employees and competition is strong, there is downward pressure on prices. ${ }^{2}$ This could impact on wages and working conditions. ${ }^{3}$ The use of child labour in this subcontracting sector has been reported. ${ }^{3}$ In 2004 it was estimated that the number of children working in surgical instrument manufacturing in Sialkot was about 5,000, of which approximately 200 were aged nine or under. ${ }^{5}$ There are also reports from Sialkot of hazardous working conditions, low pay and long working hours.

The Swedish NGO Swedwatch has also reported unethical practices in the manufacture of textiles in developing countries destined for use in uniforms for healthcare workers in Sweden. ${ }^{3}$ Similar problems have been found with the manufacture of latex and nitrile gloves for worldwide markets from Malaysia. ${ }^{13}$

\section{POLICY}

The UK has placed a high priority on corporate social responsibility including supply chain issues and international labour standards ${ }^{14}$ and has supported the Ethical Trading Initiative. ${ }^{15}$ In addition, the EU also places a strong emphasis on corporate social responsibility and international labour standards. ${ }^{10}$ The UK, in its framework for sustainable development, adopted an international stance including support for a more equitable and sustainable world. ${ }^{16}$ The International Labour Organization, of which the United Kingdom is a member, has developed international standards on occupational safety and health ${ }^{17}$ as well as workers' rights. ${ }^{18}$ The UN Global Compact, a voluntary arrangement which companies can sign up to, has a strong emphasis on responsible business practices including human rights and eliminating labour abuses. ${ }^{19}$ In 2008 NHS Purchasing and Supply Agency (PASA) produced the documents Ethical procurement for health guidance $^{11}$ and a Framework for an ethical procurement strategy for the healthcare sector. ${ }^{4}$ NHS PASA has now been decommissioned but some of NHS PASA's functions have been taken over by the Department of Health with the hope that Ethical procurement for health will soon be finalised. The NHS Supply Chain has developed a Code of Conduct which includes attention to international labour standards. ${ }^{20}$

\section{CONCLUSION}

There has been a trend for consumers in the developed world to increasingly consider ethical issues when they purchase groceries, clothing, and various other products. $^{21,22}$ However, until recently, this has received little consideration in the medical field. The scale of unethical sourcing in medicine is unknown because we may not be told, or ask where, our healthcare products are manufactured. International trade in dental instruments and materials is open to unethical sourcing because many dental goods are manufactured in the developing world.

Health benefits in the developed world should not be at the expense of the health of workers in the global community. The manufacture of instruments and other commodities in conditions which are harmful to health is at odds with this. There is evidence that some instruments and goods used in dentistry are made under unethical conditions. Work needs to be done to raise awareness at each level of the supply and purchasing chains. It would be desirable for dentists and DCPs to try to establish the origin of the instruments and materials that they use, and if this is a developing country, to inquire about labour standards. It is likely at first that information will often be difficult to obtain, largely because those towards the end of the supply chain may hold no relevant information. It is hoped, however, that increased demands for such information will result in an increase in its availability. Beyond the practising environment, the authors suggest that a collaborative approach between professional bodies and the health care manufacturing industry may be beneficial. It is noted that documents in relation to ethics available from dental professional organisations, including trade organisations and regulatory bodies, make no reference to the possible working conditions involved in manufacturing instruments and materials used in dentistry. It is suggested that recognition of the possibility of poor working conditions in the manufacture of dental goods in the wording of ethics-based documents would also be helpful.

1. Roberts $\mathrm{O}$, Bhutta $\mathrm{M}$, Bagenholm E. Bringing fair trade to health systems: what you can do. World Med J 2009; 55: 98-99.

2. Nadvi K. The cutting edge: collective efficiency and international competitiveness in Pakistan. Oxford Development Studies 1999; 27: 81-107.

3. Bjurling K. The dark side of health care. Stockholm: Swedwatch, 2007.

4. NHS Purchasing and Supply Agency. Framework for an ethical procurement strategy for the healthcare sector. Leeds: NHS Purchasing and Supply Agency, 2008

5. ILO/IPEC. Baseline survey report on child labour in surgical instruments manufacturing industry Sialkot. Lahore: ILO/IPEC, 2004

6. Bhutta M. Fair trade for surgical instruments. BMJ 2006; 333: 297-299.

7. Nadvi K, Halder G. Local clusters in global value chains: exploring dynamic linkages between Germany and Pakistan. Entrepreneurship \& Regional Development 2005; 17: 339-363.

8. Office for National Statistics. UK trade in goods analysed in terms of industries. Quarter 42009. London: The Stationery Office, 2010.

9. British Dental Association. BDA advice sheet E12. Careers in dentistry. London: British Dental Association, 2007.

10. Commission of the European Communities. Communication from the commission to the European parliament, the council and the European economic and social committee. Implementing the partnership for growth and jobs: making Europe a pole of excellence on corporate social responsibility. Brussels: Commission of the European Communities, 2006.

11. NHS Purchasing and Supply Agency. Ethical procurement for health guidance. Leeds: NHS Purchasing and Supply Agency, 2008.

12. International Labour Organisation. International labour conference, 99th session, 2010. Report of the committee of experts on the application of conventions and recommendations. Report III (Part 1A). Geneva: International Labour Office, 2010.

13. Swedwatch. Papyrus Sweden AB's purchase of nitrile gloves from Malaysia. Stockholm: Swedwatch, 2010.

14. Department of Trade and Industry. Corporate social responsibility. A government update. London: Department of Trade and Industry, 2004.

15. Ethical Trading Initiative. The ETI base code. London: Ethical Trading Initiative, 2001.

16. Department for Environment, Food and Rural Affairs. One future - different paths. The UK's 
shared framework for sustainable development. London: Department for Environment, Food and Rural Affairs, 2005.

17. International Labour Office. ILO standards on occupational safety and health. Geneva: ILO, 2009.

18. International Labour Organisation. ILO declaration on fundamental principles and rights at work 86th session. Geneva: ILO, 1998.

19. United Nations. United Nations global compact. New York: United Nations Global Compact Office, 2008.

20. NHS Supply Chain code of conduct. http://www supplychain.nhs.uk/portal/pls/portal/!PORTAL.
wwpob_page.show?_docname=3855984.PDF.

21. Shreck A. Resistance, redistribution, and power in the Fair Trade banana initiative. Agric Human Values 2005; 22: 17-29

22. De Pelsmacker P, Driesen L, Rayp G. Do consumers care about ethics? Willingness to pay for fair trade coffee. J Consum Aff 2005; 2: 363-385. 